\title{
Analysis of failures of waterproofing cladding layers of terracotta tiles
}

\author{
Milan Koláčný1, * \\ ${ }^{1}$ CTU in Prague, Faculty of Civil Engineering, Thákurova 7, 16629 Prague 6, Czech Republic
}

\begin{abstract}
The article is focused on one of the most important roof cladding layers - the waterproofing cladding layer of terracotta tiles. Its detailed analysis covers the main waterproofing cladding layers in terms of their material characteristics and installation methods. The article concludes by formulating principles for the correct design of the main waterproofing layer/construction.
\end{abstract}

\section{Introduction}

Roof cladding has been part of the main waterproofing construction in various shapes since the beginning of our era. Around the 1970s - 1980s, the attic space (usually of existing residential houses) started to be used for living or other purposes involving permanent people's presence.

One of the objectives of research was to formulate the principles for the effective design of waterproofing layers in roof cladding systems and prove the effect of the main waterproofing layer on the life span of the whole roof construction [1].

\section{Experimental verification of reliability and durability of waterproofing cladding layers}

The analysis of the mechanical and physical characteristics of waterproofing cladding layers was made on two reference houses with residential attics. The first house had a wrongly installed roof cladding without an effectively ventilated air layer and the roof tiles were locally damaged, the cladding age is 18 years, the slope of roof planes $25^{\circ}$ and $32^{\circ}$.

The second reference house had a faultlessly installed roof covering with fired clay roof tiles in accordance with regulations in force ten years ago with a slope of $40^{\circ}$.

Experimental testing covered waterproofing cladding layers installed pursuant to ČSN standards in force and manufacturer's assembly principles, including the correct workmanship of the ventilated air layer. The waterproofing cladding was subjected to impermeability and tensile bending strength tests. This experiment is focused on the properties of materials embedded in the roof envelope in direct connection to their life expectancy and mechanical and physical characteristics.

\footnotetext{
* Corresponding author: milan.kolacny.rbe@gmail.com
} 
Roof tiles were sampled from the waterproofing cladding layer of both houses and successively subjected to standard tests. To compare the characteristics, roof tiles of the original batch stored in the interiors of both houses were also tested. These roof tiles were tested for impermeability under ČSN EN 539-1 [2], testing method No. 2 and for tensile bending strength under ČSN EN 491:2012 [3].

\subsection{Mechanical and physical characteristics of waterproofing layer materials on experimental houses}

The results of the tests of mechanical and physical characteristics for differently installed roof tiles from two experimental houses "Trojanova" (without a ventilated air layer) and "U Smaltovny" (faultless roof cladding) are presented in Tables 1 and 2:

Table 1. Evaluation of the impermeability test of plain roof tiles.

\begin{tabular}{|c|c|c|c|c|c|c|c|}
\hline \multicolumn{4}{|c|}{ IMPERMEABILITY TEST - Trojanova } & \multicolumn{4}{|c|}{ IMPERMEABILITY TEST - U Smaltovny } \\
\hline \multicolumn{4}{|c|}{ Date of testing: 28.12 .2015 from $5.00 \mathrm{a} . \mathrm{m}$. } & \multicolumn{4}{|c|}{ Date of testing: 13. 1.2016 from 8.30 a.m. } \\
\hline $\begin{array}{c}\text { Speci } \\
\text { men } \\
\text { No. }\end{array}$ & $\begin{array}{c}\text { Weight } \\
{[\mathrm{g}]}\end{array}$ & $\begin{array}{l}\text { Time to first } \\
\text { drop [hours] }\end{array}$ & $\begin{array}{l}\text { Impermeability } \\
\text { coefficient }\end{array}$ & $\begin{array}{c}\text { Speci } \\
\text { men } \\
\text { No. }\end{array}$ & $\begin{array}{l}\text { Weight } \\
{[\mathrm{g}]}\end{array}$ & $\begin{array}{c}\text { Time to first drop } \\
\text { [hours] }\end{array}$ & $\begin{array}{c}\text { Impermeability } \\
\text { coefficient }\end{array}$ \\
\hline \multicolumn{4}{|c|}{ Roof tiles sampled from a cellar deposit } & \multicolumn{4}{|c|}{ Roof tiles sampled from a cellar deposit } \\
\hline N1 & 1674.2 & 2.25 & 0.888 & N1 & 1577.1 & nodrop & 0 \\
\hline $\mathrm{N} 2$ & 1678.5 & 5.5 & 0.725 & $\mathrm{~N} 2$ & 1571.8 & nodrop & 0 \\
\hline N3 & 1675.5 & 5 & 0.75 & N3 & 1567.5 & nodrop & 0 \\
\hline N4 & 1674.9 & 5 & 0.75 & $\mathrm{~N} 4$ & 1570.1 & nodrop & 0 \\
\hline \multicolumn{2}{|c|}{ Mean values } & 4.44 & 0.78 & \multicolumn{2}{|c|}{ Mean values } & & $\mathbf{0}$ \\
\hline \multicolumn{4}{|c|}{ Roof tiles embedded in the roof envelope } & \multicolumn{4}{|c|}{ Roof tiles embedded in the roof envelope } \\
\hline S1 & 1764.9 & nodrop & 0 & S1 & 1631.7 & nodrop & 0 \\
\hline S2 & 1686.8 & nodrop & 0 & S2 & 1654.6 & nodrop & 0 \\
\hline S3 & 1764.5 & nodrop & 0 & S3 & 1626.3 & nodrop & 0 \\
\hline S4 & 1772.5 & nodrop & 0 & S4 & 1624.2 & nodrop & 0 \\
\hline \multicolumn{2}{|c|}{ Mean values } & & 0 & \multicolumn{2}{|c|}{ Mean values } & & 0 \\
\hline
\end{tabular}

In the roof tiles sampled from the house with a cladding without a ventilated air layer, no leakage occurred in any of 4 embedded (used) roof tiles during the testing time, i.e. 24 hours. So-called "tightening", i.e. closing of pores occurs in the used roof cladding and, successively, the roof cladding does not leak during its life span. In the roof tiles from the deposit, which had not been exposed (embedded), the average impermeability coefficient measured from 4 specimens reached a value of 0.778 .

Laboratory tests of the roof tiles from the second reference house manifested that the roof tiles which had been embedded in a correctly installed main waterproofing cladding layer as well as the roof tiles stored in the deposit had not lost their principal property impermeability during the 10-year period. 
Table 2. Tensile bending strength of roof tiles.

\begin{tabular}{|c|c|c|c|c|c|c|c|}
\hline \multicolumn{4}{|c|}{ RH Trojanova, Prague 2} & \multicolumn{4}{|c|}{ RH U Smaltovny, Prague 7} \\
\hline \multicolumn{8}{|c|}{ TENSILE BENDING STRENGTHS OF ROOF TILES - Experiment 1 and 2} \\
\hline $\begin{array}{c}\text { Specimen } \\
\text { No. }\end{array}$ & $\begin{array}{l}\text { Weight } \\
{[\mathrm{g}]}\end{array}$ & $\begin{array}{c}\text { Hanging } \\
\text { length }[\mathrm{mm}]\end{array}$ & $\begin{array}{l}\text { Max. } \\
\text { force } \\
F[N]\end{array}$ & $\begin{array}{l}\text { Specimen } \\
\text { No. }\end{array}$ & $\begin{array}{c}\text { Weight } \\
{[\mathrm{g}]}\end{array}$ & $\begin{array}{c}\text { Hanging length } \\
{[\mathrm{mm}]}\end{array}$ & $\begin{array}{l}\text { Max. } \\
\text { force } \\
F[N]\end{array}$ \\
\hline \multicolumn{4}{|c|}{ Roof tiles embedded in the roof envelope } & \multicolumn{4}{|c|}{ Roof tiles embedded in the roof envelope } \\
\hline 1 & 1673.6 & 352 & 792 & 1 & 1631.7 & 336 & 1173 \\
\hline 2 & 1680.8 & 351 & 913 & 2 & 1645.6 & 337 & 1168 \\
\hline 3 & 1675.5 & 352 & 886 & 3 & 1626.3 & 336 & 1168 \\
\hline$X$ & - & - & - & 4 & 1624.2 & 336 & 993 \\
\hline $\begin{array}{l}\text { Mean } \\
\text { value }\end{array}$ & 1676.63 & 351.67 & 863.67 & Mean value & 16334.2 & 336.3 & 1126 \\
\hline \multicolumn{4}{|c|}{ Roof tiles sampled from a cellar deposit } & \multicolumn{4}{|c|}{ Roof tiles sampled from a cellar deposit } \\
\hline$X$ & - & - & - & 5 & 1577.1 & 349 & 1100 \\
\hline 4 & 1765.4 & 349 & 1100 & 6 & 1571.8 & 351 & 1158 \\
\hline 5 & 1687.7 & 351 & 1158 & 7 & 1567.5 & 348 & 1229 \\
\hline 6 & 1763.2 & 348 & 1229 & 8 & 1570.1 & 355 & 1346 \\
\hline $\begin{array}{l}\text { Mean } \\
\text { value }\end{array}$ & 1738.77 & 349.33 & 1162.33 & Mean value & 1571.6 & 335.8 & 1304 \\
\hline
\end{tabular}

Laboratory testing verified a decrease in the tensile bending strength of 3 specimens embedded for 18 years over an unventilated air layer by nearly $25 \%$ compared to 3 specimens of identical roof covering stored in the deposit of spare roof tiles on the first overground storey of the same house for the same period of time. On the contrary, 4 specimens embedded over a ventilated roof layer showed a decrease in the tensile bending strength of $14 \%$ after 10 years against the specimens from the deposit. In both reference houses, however, the minimum standard strength of plain terracotta roof tiles required for the whole life span of $600 \mathrm{~N}$ was observed with a reserve.

\section{Analysis of failures and defects of roof cladding envelopes}

The experiments included the assessment of the causes of failures and defects of roof cladding envelopes. Based on long-term statistics of repairs and reconstructions of $2011-$ 2015, the results presented in this study are as follows (internal statistical data of rbe Koláčný s.r.o. Company) are presented in Tables 3 and Fig. 1: 
Table 3. Causes of roof reconstructions over a period of 5 years.

\begin{tabular}{|c|c|c|c|c|c|c|c|c|c|c|c|c|c|}
\hline \multicolumn{10}{|c|}{ STATISTICS OF RECONSTRUCTIONS OF ROOFS with terracotta and concrete roof tiles } \\
\hline \multicolumn{10}{|c|}{ - } \\
\hline Cause of repair & $\mathbf{2 0 1 5}$ & \multicolumn{2}{|c|}{$\mathbf{2 0 1 4}$} & $\mathbf{2 0 1 3}$ & \multicolumn{2}{|c|}{$\mathbf{2 0 1 2}$} & \multicolumn{2}{|c|}{$\mathbf{2 0 1 1}$} & \multicolumn{2}{c|}{ Total } \\
\hline Roofs in total & 42 & $\%$ & 56 & $\%$ & 38 & $\%$ & 33 & $\%$ & 46 & $\%$ & 215 & $\%$ \\
\hline $\begin{array}{c}\text { Additionally built-in } \\
\text { attic space }\end{array}$ & 15 & $35.7 \%$ & 21 & $37.5 \%$ & 8 & $21.1 \%$ & 3 & $9.1 \%$ & 12 & $26.1 \%$ & 59 & $27 \%$ \\
\hline $\begin{array}{c}\text { Wrongly installed } \\
\text { under-roof / poor } \\
\text { workmanship }\end{array}$ & 13 & $31.0 \%$ & 10 & $17.9 \%$ & 9 & $23.7 \%$ & 2 & $6.1 \%$ & 4 & $8.7 \%$ & 38 & $18 \%$ \\
\hline $\begin{array}{c}\text { Excessive age of roof } \\
\text { covering }\end{array}$ & 14 & $33.3 \%$ & 25 & $44.6 \%$ & 21 & $55.3 \%$ & 28 & $84.8 \%$ & 30 & $65.2 \%$ & 118 & $55 \%$ \\
\hline
\end{tabular}

\section{STATISTICS OF RECONSTRUCTIONS OF ROOFS with}

\section{terracotta and concrete roof tiles}

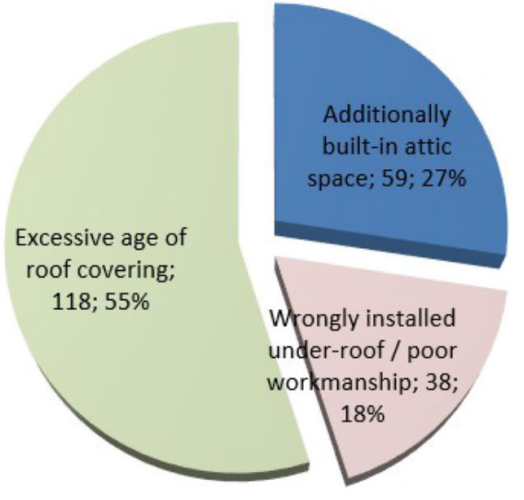

Additionally built-in attic space

Wrongly installed under-roof / poor workmanship

Excessive age of roof covering

Fig. 1. Causes of roof reconstruction over a period of 5 years - comparison.

Note: The age considered excessive is a period exceeding 60 years.

The above statistics clearly show the growing trend in repairs and reconstructions due to wrongly installed roof cladding or using unsuitable materials. These are, in particular, poorquality foils for additional waterproofing layers, which are the most frequent cause of a necessary reconstruction.

\section{Principles of effective design of main waterproofing constructions in roof cladding systems}

These are the principles for the installation of waterproofing constructions of roof envelopes and their effect on the roof construction's life span. The determination of the design life expectancy of the main waterproofing construction requires respecting Instruction F (directive of building products 89/106/EEC) and Eurocode ČSN EN 1990. The above documents recommend a design life expectancy of constructions for common buildings replaceable with some effort of 25 years, it is the life expectancy of easily replaceable constructions. The recommended life expectancy of repairable constructions is 
10 years. Therefore, according to this directive, the additional waterproofing layer should have a required life expectancy of 25 let, whereas the life expectancy of 10 years would suffice for the roof tiles. If the manufacturers of additional waterproofing layers declared a life expectancy lower than 10 years, i.e. significantly shorter than the guarantee provided by the manufacturers of roof covering systems, the guarantee for the roof covering could not be fully used.

The above facts clearly show that the life expectancy of additional waterproofing layers in the roof construction in terms of the life span of roof envelopes with a waterproofing cladding layer over residential attics is of principal importance both in terms of the roof surface area and detail.

An ideal solution in the environmental and economic perspective is to unify the durability of the main and additional waterproofing layers within the principal waterproofing construction to the maximum extent possible. This is the optimum in terms of the roof cladding cost-effectiveness.

\section{Conclusion}

The following conclusions can be drawn from the above facts for an effective design and installation of roof cladding systems:

- unify the design life span of the products of the main waterproofing construction both over the surface area and in detail,

- change the approach to the design of additional waterproofing layers (quality of material solution, change in loading, elimination of negative mechanical, UV and chemical effects),

- search for materials with long-term reliable characteristics for additional waterproofing layers.

A faultless and long-term functional principal waterproofing construction undoubtedly necessarily requires a suitable structural design of the whole roof cladding and the right choice of individual materials for each layer. The materials must be mutually compatible and their planned life expectancy should be identical or at least similar. Correct workmanship during the installation is the last condition so that the principal waterproofing construction is fully functional from the very beginning. Only if the above conditions are fulfilled, a long-lasting and perfect roof can be achieved.

\section{References}

1. M. Koláčný, The Effect of Roof Cladding on the Function of Waterproofing Layers (Unpublished)

2. ČSN EN 539-1, Fired Clay Roof Covering - Determination of Physical Characteristics, Impermeability Test (2013)

3. ČSN 491:2012, Concrete Roof Tiles and Trim Tiles for Roof Covering and Wall Cladding - Testing Methods (2012) 